\title{
Motivasi Mahasiswi Bercadar dan Responnya terhadap Stereotip Negatif Pengguna Cadar
}

\author{
Izzatur Rusuli \\ Institut Agama Islam Negeri (IAIN) Takengon Aceh
}

\begin{abstract}
This study aims to determine the motivation for Muslim women to veil and their responses to negative stereotypes directed at veil users. This research is qualitative research with a case study approach. Semistructured interviews were given to fourteen participants as a data collection technique. The data analysis in this study used three stages; data reduction, data presentation, and drawing conclusions. The results showed that mostly the veiled motivation is intrinsic motivation which is a form of religious expression from the participants and also as an effort to guard against the opposite sex. While their response to negative stereotypes is indifference and positive thinking.
\end{abstract}

Keywords: Motivation; negative stereotype; response; veil.

\begin{abstract}
Abstrak
Penelitian ini bertujuan untuk mengetahui motivasi bercadar bagi perempuan muslimah dan respon mereka terhadap stereotip negatif yang diarahkan kepada pengguna cadar. Penelitian ini merupakan penelitian yang bersifat kualitatif dengan pendekatan studi kasus. Wawancara semi terstruktur yang diberikan kepada empat belas partisipan dilakukan sebagai teknik pengumpulan data. Analisis data dalam penelitian ini menggunakan tiga tahap; reduksi data, penyajian data dan penarikan kesimpulan. Hasil penelitian menunjukkan bahwa sebagian besar motivasi bercadar adalah motivasi intrinsik yang merupakan bentuk ekspresi beragama dari partisipan dan juga sebagai upaya penjagaan dari lawan jenis. Sementara respon mereka terhadap stereotip negatif, yaitu acuh tak acuh dan berpikiran positif.
\end{abstract}

Kata kunci: Cadar; motivasi; respon; stereotip negatif.

Di era milenial ini, pakaian Muslimah yang dicirikan dengan baju gamis longgar dan jilbab panjang telah menguasai pasar sehingga berdampak kepada pergeseran makna dalam menutup aurat (Husna, 2018). Termasuk di dalamnya pemakaian cadar. Cadar merupakan selembar kain yang menutupi wajah seorang Muslimah yang hanya menyisakan dua matanya saja. 
Pemakaian cadar bagi seorang Muslimah saat ini bukanlah sesuatu yang asing lagi bagi masyarakat Indonesia. Terlebih lagi adanya komunitas niqab squad yang pernah dikupas pada acara Indonesian Lawyer Clubs (Ilyas, 2019) di salah satu stasion televisi di mana pada komunitas ini ternyata wanita bercadar banyak yang berkecimpung di dunia bisnis, fotografer handal, dunia akademisi, kesehatan dan sebagainya. Dalam acara tersebut mereka ingin menyampaikan pesan ke masyarakat bahwa penggunaan cadar tidak menghalangi karir mereka, dan mereka menggunakan cadar sebagai ekspresi beragama untuk menjalankan sunah Rasulullah SAW.

Dengan maraknya fenomena cadar, maka cadar juga menjadi perbincangan yang popular tidak hanya di dunia maya tetapi juga dunia akademis. Beberapa penelitian mengkaji cadar dari berbagai aspek seperti landasan hukumnya (Kudhori, 2019; Rasyid \& Bukido, 2018; Sudirman, 2018), apakah cadar merupakan adat Arab atau syariat Islam? (Aziz, 2018) juga meneliti tentang cadar dari segi historisnya (Afifah, 2019). Tidak hanya itu, cadar juga diteliti dari aspek psikologis seperti bagaimana komunikasi interpersonalnya (Sahfitri, 2017), bagaimana Muslimah bercadar memaknai cadarnya (Mahanani, 2017; Qolbi \& Haidar, 2013), dan bagaimana Muslimah bercadar menyesuaikan diri dengan masyarakat di sekitarnya (Sari, Lilik, \& Agustin, 2014), serta stigma yang diperoleh Muslimah bercadar dan bagaimana cara mengatasinya (Juliani, 2018; Rahman \& Syafiq, 2017).

Tidak hanya di dalam negeri, fenomena cadar sudah lebih awal menjadi perbincangan di kalangan akademisi internasional beberapa tahun yang silam seperti Eaton (2015) yang meneliti fenomena hijab, pakaian longgar dan religiusitas muslimah di USA. Hasil penelitian kuantitatifnya menunjukkan bahwa perempuan yang memakai pakaian longgar mempunyai hubungan negatif dengan internalisasi sikap depresi dan ketakutan. Artinya Muslimah yang berpakaian longgar (loose-fitted clothing) tidak akan mengalami depresi dan ketakutan. Sementara tingkat religiusitas seorang Muslimah juga mempunyai hubungan yang negatif dengan internalisasi psikopatologi dalam hal ini depresi dan ketakutan. Artinya Muslimah yang mempunyai tingkat religiusitas tinggi, maka semakin rendah depresi dan ketakutan yang dialaminya. 
Berbeda dengan penelitian yang dilakukan oleh Nasser (1999) yang melihat bahwa perlunya analisis yang mendalam terhadap eksistensi pemakaian cadar saat ini. Apakah ini sebuah bentuk kebangkitan Islam kembali atau mengaktifkan kembali tradisi dahulu? Hasil penelitiannya menunjukkan bahwa pilihan memakai cadar lebih disebabkan karena kelas ekonomi sosial. Selain itu, pemakaian cadar merupakan pilihan bagi perempuan kelas menengah ke bawah.

Sementara itu, Sircar (2015) melakukan penelitian yang mengkaji cadar dari perspektif hukumnya. Yang menjadi permasalahan dalam penelitiannya adalah apakah memakai cadar itu kewajiban bagi seorang Muslimah atau hanya sebagai anjuran. Hasil penelitiannya menunjukkan bahwa dalam al-Qur'an yang secara khusus membahas tentang cadar hanya sedikit. Maka diberikan kebebasan bagi individu muslim untuk menginterpretasikan hukum cadar yang ada dalam al-Qur'an.

Penelitian Sircar sejalan dengan Neill, Gidengil, Côté, \& Young (2015) yang menyatakan bahwa cadar merupakan bentuk kebebasan beragama bagi perempuan dan kebebasan ini juga didukung oleh kaum feminis non-muslim di ruang publik. Hasil penelitiannya menunjukkan bahwa mereka (kaum feminis non-muslim) adalah wanita muda yang lebih terbuka sehingga mudah menerima perbedaan. Selain itu, Leach et al., (2016) menyimpulkan bahwa pemakaian cadar (veil) di negara Amerika, Inggris dan Kanada tidak mengganggu kesaksian. Hal ini disebabkan perempuan yang mengenakan cadar selalu mengatakan yang sebenarnya.

Sementara itu Husain \& Aziz (2014) meneliti tentang pandangan body esteem (penghargaan terhadap tubuhnya) antara perempuan yang bercadar dengan perempuan yang tidak bercadar di Pakistan. Hasil penelitiannya menunjukkan bahwa perempuan yang bercadar mempunyai harga diri lebih tinggi terhadap tubuhnya dibandingkan dengan perempuan yang tidak bercadar.

Walaupun geliat pemakaian cadar di era ini bukanlah sesuatu yang asing di masyarakat, namun stereotip negatif yang dilekatkan kepada mereka juga masih ada seperti mereka mempunyai paham radikalisme, dianggap teroris, menganut Islam ekstrimis dan sebagainya (Husna, 2018; Juliani, 2018; Qolbi \& Haidar, 2013; Ratri, 2011). Bahkan salah satu rektor kampus Islam melarang pemakaian cadar bagi mahasiswinya (Kudhori, 2019) karena mahasiswi yang 
bercadar dianggap memiliki paham Islam radikal dan mengganggu proses perkuliahan (Juliani, 2018).

Stereotip negatif terhadap penggunaan cadar masih dilebelkan oleh sebagian masyarakat Indonesia. Hal ini Berdasarkan penelitian Amanda \& Mardianto (2014) yang menyimpulkan adanya hubungan yang positif antara prasangka dan jarak sosial dengan Muslimah bercadar. Ini berarti masyarakat masih mempunyai prasangka yang negatif terhadap Muslimah bercadar dan mereka juga mengambil jarak ketika berinteraksi dengan Muslimah bercadar. Ini disebabkan sebagian perempuan yang bercadar cenderung bersifat tertutup daripada membuka diri dalam pergaulan. Sebagaimana penelitian yang dilakukan oleh Juliani (2018) yang menyatakan bahwa adanya perubahan yang terjadi pada mahasiswi yang bercadar menjadi lebih pendiam, tidak suka berkumpul dengan banyak orang, suka mengasingkan diri, dan memilih-milih teman dalam bergaul.

Yang menjadi permasalahan adalah di era milenial saat ini, fenomena perempuan bercadar sering dijumpai, baik di dunia maya maupun di dunia nyata walaupun sebagian besar masyarakat masih memberikan stereotip negatif terhadap mereka. Kondisi ini juga terjadi pada mahasiswi di Institut Agama Islam Negeri (IAIN) Takengon dimana peneliti melihat adanya peningkatan jumlah mahasiswi yang menggunakan cadar. Oleh karena itu, hal ini sangat menarik untuk diteliti tentang apa motivasi mereka menggunakan cadar dan bagaimana respon mereka tentang stereotip negatif terhadap pemakai cadar?

\section{Metode}

Penelitian ini merupakan penelitian kualitatif, yaitu penelitian yang menggunakan data berbentuk kata dan kalimat sebagai hasil penelitiannya. Metode kualitatif digunakan untuk mendapatkan data yang mendalam yaitu suatu data yang mengandung makna. Oleh karena itu, penelitian kualitatif tidak menekankan kepada generalisasi tetapi lebih kepada makna (Sugiyono, 2014). Pendekatan yang digunakan dalam penelitian kualitatif ini adalah studi kasus dimana peneliti menggali informasi tentang motivasi mahasiswi dalam menggunakan cadar dan bagaimana respon mereka terhadap stereotip negatif tentang pengguna cadar pada lingkungan IAIN Takengon. 
Partisipan dalam penelitian ini terdiri dari 14 mahasiswi bercadar dengan lamanya menggunakan cadar antara tiga bulan sampai dua tahun, namun rata-rata partisipan sudah menggunakan cadar selama satu tahun sebagaimana tabel di bawah ini

Tabel 1

\begin{tabular}{ccc}
\multicolumn{3}{c}{ Partisipan Penelitian } \\
\hline Partisipan & Lamanya bercadar & Usia \\
\hline P1 & 2 tahun & 21 \\
P2 & 1 tahun & 20 \\
P3 & 5 bulan & 19 \\
P4 & 1 tahun & 19 \\
P5 & 1 tahun & 20 \\
P6 & 1 tahun & 19 \\
P7 & 2 tahun & 20 \\
P8 & 3 bulan & 18 \\
P9 & 2 tahun & 20 \\
P10 & 5 bulan & 19 \\
P11 & 1 tahun & 20 \\
P12 & 1,5 tahun & 21 \\
P13 & 1 tahun & 20 \\
P14 & 5 bulan & 19 \\
\hline
\end{tabular}

Partisipan adalah mahasiswi yang sedang menempuh pendidikan di IAIN Takengon dari berbagai program studi dan jurusan. Adapun teknik pengumpulan data yang peneliti gunakan adalah wawancara dengan jenis wawancara semi terstruktur. Dalam hal ini peneliti sudah menyiapkan pedoman wawancara sebagai panduan, tetapi di lapangan masih memberikan peluang pertanyaan terbuka guna mendapatkan informasi lebih lanjut dan mendalam. Contoh pertanyaan yang diberikan adalah apa yang memotivasi saudari untuk menggunakan cadar? Bagaimana pandangan saudari tentang stereotip negatif yang diberikan kepada pengguna cadar?

Teknik analisis data dalam penelitian ini menggunakan model Miles dan Huberman yang terdiri dari tiga langkah, yaitu reduksi data (data reduction), penyajian data (data display) dan penarikan kesimpulan (conclusion drawing) (Sugiyono, 2014). Dalam penelitian ini, peneliti mereduksi data yang telah terkumpul melalui wawancara dengan mengkategorikan data berdasarkan rumusan masalahnya dan membuang data-data yang tidak relevan dengan rumusan masalah. Setelah itu peneliti menyajikan data agar data lebih terorganisir dan 
tersusun dalam pola keterkaitan antara variabel yang diteliti sehingga data akan lebih mudah dipahami. Langkah berikutnya adalah penarikan kesimpulan dan verifikasi.

\section{$\mathrm{H}$ a $\mathrm{s}$ i 1}

\section{Motivasi Mahasiswi dalam Menggunakan Cadar}

Dari hasil wawancara menunjukkan bahwa kebanyakan motivasi yang melatarbelakangi partisipan menggunakan cadar adalah berupa motivasi intrinsik yaitu karena ingin mengamalkan sunah rasulullah SAW dan sebagai upaya penjagaan diri dari lelaki yang bukan mahramnya. Hal ini sebagaimana hasil wawancara berikut:

awalnya saya mencari tahu hukum menggunakan cadar dari keempat imam yang kuat yang semuanya sepakat bahwa cadar adalah sunnah yang akan berpotensi wajib apabila menimbulkan fitnah. Saya merasa cadar bukan hanya sekedar kain penutup wajah tetapi sebagai benteng untuk melindungi diri dari pandangan laki-laki yang menimbulkan syahwat (P1, 18 Juli 2019)

Pendapat di atas juga dibenarkan oleh tiga partisipan lainnya, yaitu partisipan keempat, partisipan kelima dan juga partisipan kesembilan.

Sementara motivasi dari partisipan kedelapan dalam bercadar ialah malu dengan ibunya yang sudah terlebih dahulu menggunakan cadar. Hal ini sebagaimana diungkapkan:

saya memakai cadar bermula dari niat tersendiri kemudian merasa malu terhadap ibu kandung saya yang sudah menggunakan cadar. Dari situ saya semakin fokus dan tertarik untuk mempelajari hukum bercadar. (P8, wawancara. 2019, Juli 18)

Lain halnya dengan apa yang menjadi motivasi penggunaan cadar yang disampaikan oleh partisipan ke dua ialah karena melihat fenomena degradasi moral di era kontemporer ini sehingga penggunaan cadar sebagai tameng baginya dari kerusakan moral tersebut.

yang melatarbelakangi saya menggunakan cadar mungkin karena di era modern ini saya melihat begitu rusaknya akhlak pergaulan remaja dan saya takut saya seperti itu. Karena itulah saya ingin berkomitmen dengan diri saya sendiri agar bisa istiqamah untuk berubah menjadi lebih baik. (P2, wawancara. 2019, Juli 18)

Sementara partisipan lainnya ada yang menggunakan cadar karena motivasi dari luar berupa intensitas berinteraksi dengan Muslimah yang bercadar lainnya dan merasa kagum 
dengan perempuan bercadar sehingga mengikuti jejak mereka. Hal ini sebagaimana hasil wawancara berikut:

awalnya saya sering membaca buku tentang fiqih wanita dan memasuki (mengikuti) kajiankajian di wilayah Takengon. Banyak anggota kajian yang menggunakan cadar. Saya sering bergaul dengan mereka dan saya juga termasuk pengagum wanita bercadar. (P6, wawancara. 2019, Juli 19).

Berbeda dengan partisipan kesepuluh yang niat semula memakai cadar adalah karena merasa nyaman memakai masker sehingga dilanjutkan dengan menggunakan cadar.

saya kan kak merasa bahwa cadar menjadi penjaga. Awalnya saya hanya memakai masker tapi kemudian saya merasa nyaman jika tertutup seperti itu lalu saya menggantinya dengan cadar. Dan ini menjadi motivasi bagi saya untuk terus berubah menjadi lebih baik. (P10, wawancara. 2019 Juli 18)

Dalam mempertahankan motivasi penggunaan cadar, sebagian besar partisipan mendapatkan dukungan; baik dari keluarganya, orang tuanya maupun teman-temannya sehingga membuat mereka tetap konsisten dan komitmen dalam menggunakan cadar. Selain itu, mereka juga memiliki komunitas dengan komitmen yang sama.

Tidak hanya itu, mereka tetap bertahan dengan penggunaan cadar juga disebabkan sebagian besar mereka tidak mendapatkan intimidasi maupun stereotip negatif dari lingkungan termasuk lingkungan kampus, bahkan mereka lebih dihormati dan disegani. Hal ini sebagaimana hasil wawancara berikut:

alhamdulillah kak di lingkungan kampus, mereka tidak membeda-bedakan saya yang menggunakan cadar. Bahkan dengan cadar ini saya merasa dihormati sebagai perempuan. (P5, wawancara. 2019 Juli 19)

Bahkan partisipan keempat dan kedua merasa mereka yang menggunakan cadar mendapatkan perlakukan yang istimewa karena mereka lebih dihormati dan tidak diganggu. Sebagaimana hasil wawancara berikut:

saya mendapatkan perlakuan yang istimewa baik di kampus ataupun di lingkungan sekitar. Saya merasa dihormati dan disegani oleh laki-laki yang mengganggu berupa candaan maupun hal-hal yang tidak seharusnya dilakukan contoh bercampur baur. (P4, wawancara. 2019 Juli 19) 
Namun demikian, salah satu partisipan pernah mendapatkan intimdasi karena menggunakan cadar tetapi hal itu tidak berlangsung lama. Hal ini sebagaimana hasil wawancara berikut:

Saya mendapatkan intimidasi karena menggunakan cadar. Bentuk intimidasinya hanya dijauhkan saja beberapa waktu. Tetapi setelah Allah lembutkan hati mereka, maka dengan sendirinya yang bengkok menjadi lurus bahkan sekarang saya mendapatkan teman-teman saudara yang memperkuat penggunaan cadar saya. (P4, wawancara. 2019 Juli 19).

Berdasarkan hasil wawancara di atas, menunjukkan bahwa sebagian partisipan menggunakan cadar dikarenakan motivasi intrinsik yaitu sebagai bentuk ekspresi dalam beragama. Namun sebagian yang lain menggunakan cadar dikarenakan motivasi ekstrinsik yaitu malu terhadap ibunya dan ketertarikan dengan perempuan lain yang sudah menggunakan cadar. Ketika mereka menggunakan cadar, keberadaan mereka diterima oleh lingkungan di sekitarnya dan mereka tidak mendapatkan intimidasi apapun.

\section{Respon mahasiswi bercadar tentang Stereotip negatif terhadap pengguna cadar}

Fenomena yang terjadi di saat ini, masyarakat memberikan stereotip negatif terhadap Muslimah yang menggunakan cadar, seperti dianggap sebagai teroris, menganut Islam radikal maupun terkesan bersifat tertutup yaitu kurang bersosial dengan masyarakat di sekitarnya. Berdasarkan hasil wawancara dengan partisipan menunjukkan bahwa sebagian besar mereka tidak mempedulikan stereotip negatif yang dilabelkan pada pengguna cadar. Hal ini sebagaimana hasil wawancara berikut:

jujur sebenarnya saya tidak begitu peduli dengan hal tersebut selama hal itu tidak mengganggu kenyamanan saya. Karena saya lebih fokus dengan tujuan saya (P2, wawancara. 2019, Juli 18).

Pernyataan di atas juga dibenarkan oleh partisipan kesepuluh ditambah lagi usahanya untuk memberi pemahaman bahwa pengguna cadar bukanlah teroris.

saya tidak terlalu mempedulikan label negatif itu. Saya hanya mengatakan kepada mereka yang melebeli bahwa cadar bukanlah lambang dari teroris. (P10, wawancara. 2019 Juli 18)

Hal senada juga disampaikan oleh partisipan kedelapan dan ketiga belas yang bersikap biasa saja dengan stereotip negatif tersebut. Sebagaimana hasil wawancara berikut: 
bersikap biasa dan menganggap mereka tidak tahu tentang cadar dan hukum memakai cadar. (P13, wawancara. 2019, Juli 20)

Sikap yang sama juga dilakukan oleh partisipan lain yang tidak peduli dengan stereotip tersebut bahkan menganggap bahwa radikal merupakan sebuah keniscayaan, sebagaimana hasil wawancara berikut:

mereka menganggap yang bercadar seperti itu. Tetapi mereka sendiri tidak paham dengan apa yang mereka bicarakan. Seharusnya kita sebagai Muslimah haruslah radikal dalam artian keteguhannya dan keterikatannya dengan hukum syara'. (P1, wawancara. 2019, Juli 18)

Pendapat di atas didukung oleh pendapat partisipan lainnya yang menyatakan bahwa seharusnya seorang muslim itu radikal dalam menjalankan agamanya. Sementara, label-label negatif yang diberikan kepada orang Islam dikarenakan mereka tidak suka dengan Islam. Hal ini sebagaimana wawancara berikut:

kan gini kak, bukankah orang yang menegakkan sunah Rasulullah adalah orang-orang yang terasing? Kenapa yang pakai cadar dianggap radikal? Karena mereka yang mengatakan radikal tidak nyaman dengan kelembutan Islam sehingga Islam dikasih label radikal. Kenapa ekstrim? Karena liberal merasa risih dengan indahnya aturan Islam. Kenapa dianggap eksklusif? Bukankah mutiara hanya ada di dasar lautan bukan di pinggir jalan? Maka, saya sih nggak perlu mengambil pusing dengan pendapat mereka. Kita doakan saja agar mereka cepat Allah lembutkan hati mereka sehingga mereka tau tentang fungsi cadar yang sebenarnya. (P4, wawancara. 2019 Juli 19)

Hal yang sama juga disampaikan oleh partisipan ketujuh yang menganggap bahwa mereka yang memberikan vonis negatif karena tidak mengetahui makna dari cadar itu sendiri dan bisa jadi label itu karena ada oknum Muslimah bercadar yang menyalahgunakan fungsi cadar tersebut.

Kalau menurut saya kak ya, kebanyakan orang yang memvonis adalah orang yang kurang mengenal wanita bercadar atau kurang memahami etika cadar serta fungsinya. Sebagian lain mungkin karena pernah menemui atau melihat orang yang bercadar menyalahgunakan etika dan fungsi cadar. (P7, wawancara. 2019, Juli 19)

Namun demikian, sebagian partisipan menyayangkan dengan adanya stereotip bahwa pengguna cadar adalah radikal atau teroris sebagaimana hasil wawancara sebagai berikut: 
saya sangat sedih dan merasa bahwa cadar hanya lambang dan logo dari terorisme yang bahwasannya cadar merupakan sunnatullah. Hanya saja dikarenakan beberapa oknum yang tidak bertanggung jawab melakukan kegiatan radikal tersebut, semua yang bercadar dianggap sedemikan juga. Allahul musta'an. (P14, wawancara. 2019. Juli 20)

Pendapat di atas juga didukung oleh partisipan ketiga yang menyatakan bahwa:

sangat sedih mendengar mereka mengatakan bahwa cadar adalah lambang daripada teroris. Padahal cadar adalah sunnatullah hanya saja banyak oknum yang tidak bertanggunjawab melakukan beberapa kegiatan ekstrim dengan menggunakan cadar. Makanya banyak yang menganggap cadar sebagai suatu yang berbahaya. (P3, wawancara. 2019, Juli 19)

Walau bagaimanapun sebagian partisipan menanggapi stereotip negatif tersebut dengan sikap positif yang menganggap bahwa yang memberikan label tersebut tidak mengetahui tentang fungsi cadar itu sendiri. Hal ini sebagaimana yang tersirat dalam hasil wawancara dengan partisipan kelima dan kedua belas.

berbaik sangka kepada mereka karena mungkin mereka sendiri tidak tahu fungsi dari cadar itu sendiri. Dan mereka sering melihat bahwa aksi-aksi teroris sering dikaitkan dengan cadar baik itu di media sosial maupun televisi sehingga masyarakat banyak yang berfikiran seperti itu." (P5, wawancara. 2019 Juli 19)

Bahkan ada salah satu partisipan yang menafikan stereotip negatif tersebut karena menganggap bahwa saat ini masyarakat sudah pintar sehingga lebih terbuka dengan adanya perbedaan. Sebagaimana hasil wawancara berikut:

mungkin banyak yang mengatakan teroris apalah, tapi sekarang masyarakat mulai pintar, mereka sudah mulai menerima karena sudah banyak yang paham tentang yang sebenarnya.

(P11, wawancara. 2019, 20)

Berdasarkan hasil wawancara di atas, dapat disimpulkan bahwa sebagian besar mahasiswi yang menggunakan cadar tidak mempedulikan stereotip negatif yang diberikan kepada mereka bahkan sebagian dari mereka ada yang berpikiran positif dengan mendoakan orang-orang yang memberikan label negatif tersebut. Namun sebagian kecil dari mereka ada yang menyayangkan adanya stereotip negatif tersebut dan dianggap yang memberikan label tidak memahami makna dan fungsi penggunaan cadar. 


\section{Pembahasan}

Berdasarkan hasil penelitian di atas, maka motivasi partisipan dalam menggunakan cadar dapat dikategorikan dalam dua kelompok. Pertama, partisipan yang mempunyai motivasi intrinsik yaitu ingin menjalankan sunnah Rasulullah sekaligus untuk melindungi dan menjaga diri dari pandangan, gangguan maupun fitnah lelaki yang bukan mahramnya. Hasil penelitian ini sejalan dengan penelitian Rahman \& Syafiq (2017) yang menyatakan bahwa motivasi perempuan bercadar bukan hanya karena ibadah melainkan juga sebagai cara perlindungan dalam hubungan sosial dengan lawan jenisnya. Ketika mereka menggunakan cadar, mereka merasa nyaman dan aman dari gangguan lelaki baik berupa candaan. Bahkan mereka merasa lebih disegani dan dihormati. Berbeda dengan Muslimah yang yang tidak rapi dalam menutup aurat, lelaki masih berani menggoda mereka walaupun sudah berjilbab. Motivasi intrinsik lainnya adalah kenyamanan. Dalam hal ini partisipan merasa nyaman ketika menggunakan penutup muka berupa masker, sehingga berlanjut dengan menggunakan cadar. Hal ini sesuai dengan teori motivasi Maslow (Andjarwati, 2015) di mana adanya hirerarki kebutuhan yang harus dipenuhi sehingga mendorong seseorang untuk melakukan sesuatu. Dalam konteks penelitian ini partisipan termotivasi untuk memenuhi kebutuhan tingkatan yang kedua yaitu kenyamanan sehingga dia tergerak untuk menggunakan cadar.

Notoatmodjo (2009) menyebutkan motivasi intrinsic lainnya yang bersumber dari kebutuhan dan tujuan. Di sini partisipan yang menggunakan cadar mempunyai tujuan yaitu menjalankan ajaran agamanya ditambah pula dikarenakan adanya kebutuhan yang harus dipenuhi dalam hal perlindungan diri dan mereka dapat mencapai tujuan dan terpenuhi kebutuhannya dengan menggunakan cadar.

Dalam penelitian ini, motivasi intrinsik tersebut juga muncul dari pemahaman yang mereka yakini setelah mereka membaca buku maupun mengikuti kajian-kajian keislaman sehingga membuka mata hati mereka untuk menggunakan cadar. Apabila suatu perbuatan dilakukan atas dasar motivasi intrinsik, maka perbuatan tersebut lebih bertahan untuk tetap dilakukan daripada perubahan tingkah laku yang didorong oleh motivasi ekstrinsik. Dan keyakinan mereka untuk menggunakan cadar semakin kuat ketika mereka merasa nyaman 
setelah menggunakannya. Hal ini sebagaimana yang diungkapkan oleh Eaton (2015) bahwa tingkat keberagamaan individu dapat mempengaruhi kesejahteraan hidupnya, artinya semakin baik pemahaman agamanya, maka semakin tenang hidupnya. Selain itu, partisipan merasa perbuatannya menjadi lebih terarah, mereka bisa menjadi individu yang lebih baik dan yang paling penting mereka merasa terhindar dari gangguan lawan jenis (Juliani, 2018; Rahman \& Syafiq, 2017).

Kelompok kedua yang mempunyai motivasi ekstrinsik dalam menggunakan cadar dikarenakan ikut-ikutan. Hasil penelitian menunjukkan bahwa ada salah satu partisipan yang menggunakan cadar dikarenakan merasa malu dengan ibunya yang sudah lama memakai cadar sehingga dia pun mengikuti jejak ibunya. Sedangkan partisipan lain motivasinya memakai cadar karena merasa kagum dan salut dengan kepribadian pengguna cadar dalam komunitas kajian keislaman yang pada akhirnya dia pun tertarik untuk menggunakan cadar. Di sini menunjukkan bahwa motivasi ekstrinsik yang dimiliki oleh partisipan dipengaruhi oleh significant other, yaitu individu-individu yang dekat dengan partisipan, dalam hal ini ibunya dan Muslimah lain yang ada di sekitar partisipan.

Dalam hal ini jika motivasi beragama individu bersifat ekstrinsik, dikhawatirkan ia mudah kembali lagi kepada keadaan semula apabila tidak ada inidividu lain yang turut membentinginya. Maka sebisa mungkin motivasi ekstrinsik tersebut diubah menjadi motivasi intrinsik agar perubahan yang dialami setelah menggunakan cadar bersifat konstan dan mereka tetap konsisten dalam menggunakan cadar.

Hasil penelitian ini berbeda dengan penelitian yang dilakukan oleh Qolbi \& Haidar (2013) dimana motivasi mahasiswi yang memakai cadar di kampus Institut Keislaman Abdullah Faqih (INKAFA) Gresik dikarenakan adanya kewajiban akademik yang harus dilakukan oleh setiap mahasiswi yang belajar di kampus tersebut. Karena motivasi menggunakan cadar bagi mahasiswi tersebut adalah motivasi ekstrinsik, maka ketika mereka tidak berada di kampus atau tidak melakukan aktivitas perkuliahan, mereka membuka cadar di luar kampus, artinya penggunaan cadar mereka tidak konsisten.

Berdasarkan penelitian ini, motif penggunaan cadar yang dilakukan oleh partisipan merupakan bentuk dari ekspresi beragama, tidak hanya ikut-ikutan fashion yang lagi tren. 
Menurut Ahmad (2014) ekspresi beragama merupakan sebuah usaha yang dilakukan oleh seseorang atau komunitas yang terkait dengan penggambaran perasaan baik berupa penampilan wajah, respon tubuh, kata-kata, simbol dan pengungkapan kesan-kesan yang diterima terkait dengan pengamalan keagamaan dan ritual keagamaan yang dijalankan. Dalam penelitian ini ekspresi beragama partisipan dapat dilihat dari penampilannya yang merupakan simbol dari ajaran Islam dan keyakinan mereka yang kuat memegang doktrin tentang penggunaan cadar.

Untuk menjaga komitmen menggunakan cadar, para partisipan mendapatkan dukungan dari orang tua mereka, bahkan teman-teman mereka. Di samping itu mereka juga secara aktif mengikuti kajian-kajian keislaman yang di dalamnya terdapat komunitas Muslimah bercadar. Dengan demikian, mereka tetap bertahan walaupun mendapatkan stereotip negatif. Hal ini sesuai dengan

Berkaitan dengan intimidasi, para partisipan pada umumnya tidak pernah mendapatkan intimidasi dimanapun mereka berada, baik di lingkungan kampus maupun di luar kampus. Kalaupun ada, hanya bersifat sementara dan lama kelamaan keberadaan mereka dengan performa yang berbeda bisa diterima. Bahkan partisipan merasa ketika mereka menggunakan cadar mereka diperlakukan istimewa daripada mahasiswi lainnya yang tidak menggunakan cadar. Mereka lebih dihormati dan disegani oleh orang yang berkomunikasi dengan mereka. Dengan demikian, para partisipan tidak mengalami stereotip negatif terhadap penggunaan cadar mereka. Hasil penelitian ini sejalan dengan penelitian yang dilakukan oleh Juliani (2018) yang mana mahasiswi bercadar yang mengenyam pendidikan di Universitas Teuku Umar (UTU) Meulaboh tidak mendapatkan stigma negatif di lingkungan kampus, bahkan para akademisi bersikap positif terhadap mereka.

Fenomena ini bisa terjadi dikarenakan masyarakat Aceh sudah mengaplikasikan pelaksanaan syariat Islam sehingga terbiasa dengan kondisi suasana berhijab. Oleh karena itu, keberadaan Muslimah yang bercadar tidak memberikan efek negatif terhadap mereka.

Sementara itu, berkaitan dengan stereotip negatif pengguna cadar yang dilabeli dengan teroris, radikal, eksklusif dan sebagainya merupakan ejekan atau gambaran tertentu yang diberikan kepada kelompok tertentu. Seterotip ini merupakan suatu konsepsi yang tetap yang 
melekat kepada komunitas tertentu dan stereotip ini sulit berubah meskipun berbeda dengan yang sebenarnya (Mufid, 2012). Dalam hal ini Lippman (dalam Mufid, 2012) mengatakan bahwa stereotip adalah cara ekonomis dalam melihat dunia. Sesuatu yang paling berperan di sini adalah media, karena media mampu menyuguhkan fenomena dunia atau kejadian yang berlangsung bersamaan dalam satu waktu. Dan kebanyakannya media menginformasikan bahwa kelompok Islam yang dianggap "teroris" mereka yang istrinya menggunakan cadar.

Dalam hal ini pandangan partisipan terbagi menjadi dua yaitu pandangan acuh tak acuh dan pandangan positif. Pandangan acuh tak acuh ditunjukkan oleh sebagian partisipan yang tidak peduli dengan label tersebut, tetapi sebagian lagi menyayangkan ketika pengguna cadar dikaitkan dengan istilah yang negatif dan mengerikan. Sedangkan pandangan positif dengan label negatif itu ditunjukkan dengan positive thinking mereka.

Partisipan yang tidak peduli dengan stereotip negatif tersebut berpendapat jika hal tersebut tidak mengganggu kenyamananya dalam menggapai tujuannya, maka tidak masalah. Yang penting bagi mereka adalah mereka tetap bisa beraktivitas sebagaimana Muslimah lainnya. Sementara partisipan yang menyayangkan adanya stereotip tersebut merasa sedih dan miris, karena adanya paparan dari media online yang memperlihatkan pengguna cadar yang melakukan perbuatan melanggar hukum dengan cara kekerasan, sehingga mereka yang menggunakan cadar tetapi tidak melakukannya juga terkena imbasnya.

Sedangkan partisipan yang bersikap positif terhadap sterotip tersebut tetap berbaik sangka dengan sangkaan bahwa yang melabelkan label negatif tersebut tidak mengetahui hakikat penggunaan cadar dan manfaat besar yang akan didapatkan. Partisipan akan bersikap baik dan lemah lembut ketika bersosialisasi sehingga harapannya dapat merubah image mereka tentang pengguna cadar sehingga mereka tidak dilabeli negatif. Mereka hanya mendoakan agar yang memberikan label negatif terbuka hatinya untuk bisa menerima cadar. Bahkan salah satu partisipan berpandangan bahwa di era saat ini masyarakat sudah terbuka pikirannya, sehingga bisa menerima keberadaan penggunaan cadar di sekitar mereka sehingga label-label negatif yang diberikan kepada pengguna cadar tidak membuat mereka mengeneralisasikan kepada pengguna cadar lain. 
Hasil penelitian ini sejalan dengan penelitian Rahman \& Syafiq (2017) yang menyatakan bahwa di antara coping yang dilakukan oleh perempuan bercadar dalam menghadapi stigma tersebut adalah dengan menggunakan dua pendekatan, yaitu pendekatan kognitif dan pendekatan sosial. Pendekatan kognitif mengacu kepada mengolah pola pikiran dalam menghadapi stigma negatif yang dilabelkan kepada mereka. Sedangkan pendekatan sosial adalah dilakukan dengan cara membaur dan bersosialisasi dengan masyarakat sehingga kesan ekslusif dari mereka dapat ditepis.

Namun demikian, terdapat salah satu partisipan yang bahkan setuju dengan stereotip yang diberikan dan membenarkan label tersebut dengan menyatakan bahwa memang umat Islam harus terasing, radikal, dan eksklusif. Dengan alasan memang Islam datang dalam kondisi terasing, maka tidak masalah jika hidup dalam kondisi terasing, berbeda dengan yang lainnya. Sementara dikatakan radikal, maka umat Islam seharusnya mempunyai pemahaman yang radikal karena dalam kamus Bahasa Indonesia radikal berarti secara menyeluruh dan habis-habisan (Tim Penyusun Kamus Pusat Bahasa, 2008). Artinya seorang muslim sejati harus mengamalkan ajaran Islam secara menyeluruh. Bahkan umat Islam diperintahkan untuk masuk Islam secara menyeluruh atau sempurna (kaffah). Sementara pandangan eksklusif dimaknakan sebagai pergaulan yang terjaga karena mutiara itu hanya diperoleh di dasar lautan bukan di pinggir jalan. Artinya sebagai Muslimah harus bisa menjaga dirinya jangan sampai mudah diganggu atau digoda oleh lawan jenis yang berniat jahat.

\section{Kesimpulan}

Menggunakan cadar merupakan sebuah pilihan yang diberikan kebebasan kepada Muslimah untuk memutuskan secara pribadi. Motivasi menggunakan cadar pada penelitian sebagian besarnya merupakan motivasi intrinsik yang datangnya dari diri sendiri tanpa adanya paksaan dari luar. Motivasi mereka didorong untuk melakukan sunah Rasulullah dan melindungi diri mereka dari gangguan lawan jenis. Mereka tidak peduli dengan adanya stereotip yang dilabelkan terhadap pengguna cadar walaupun sebagiannya merasa sedih dengan pelabelan tersebut. Tetapi stererotip negatif tersebut tidak membuat mereka goyah untuk melepaskan cadar mereka. Bahkan di lingkungan mereka sendiri, mereka tidak 
mendapatkan stigma tersebut. Implikasi dari penelitian ini adalah diharapkan masyarakat tidak memandang sebelah mata terhadap perempuan bercadar karena pada hakikatnya seperti itu ekspresi beragama mereka. Sementara kepada pengguna cadar diharapkan lebih bersifat inklusif sehingga keberadaan mereka bisa diterima oleh masyarakat di sekitar mereka.

\section{Saran}

Disarankan kepada siapapun untuk menghormati pilihan Muslimah yang menggunakan cadar sebagai bentuk ekspresi beragama mereka. Hal ini bisa dilakukan dengan tidak mendiskriminasikan mereka dalam memberikan pelayanan maupun dalam bersosialisasi. Kepada Muslimah yang bercadar diharapkan juga untuk membuka diri untuk bersosial dengan siapapun tanpa membedakan-bedakan.

\section{Referensi}

Afifah, N. (2019). Cadar dan ruang kontestasi penafsiran otoritatif. Religia, 22(1), 17-32.

Ahmad, H. Z. R. (2014). Ekspresi keagamaan, dan narasi identitas: Studi program pesantren tahfidz intensif Daarul Quran Cipondoh Tangerang. Jurnal Multikultural Dan Multireligius, 13(2), 51-69.

Amanda, R., \& Mardianto. (2014). Hubungan antara prasangka masyarakat terhadap muslimah bercadar dengan jarak sosial. Jurnal RAP UNP, 5(1), 72-81. Retrieved from http://ejournal.unp.ac.id/index.php/psikologi/article/view/6642

Andjarwati, T. (2015). Motivasi dari sudut pandang teori hirarki kebutuhan Maslow, teori dua faktor Herzberg, teori X Y Mc Gregor, dan teori Motivasi prestasi Mc Clelland. JMM17: Jurnal Ilmu Ekonomi \& Manajemen, 1(1), 45-54.

Aziz, A. (2018). Perempuan bercadar: Antara budaya dan syari'ah. Jurnal Darussalam; Jurnal Pendidikan, Komunikasi Dan Pemikiran Hukum Islam, X(1), 196-211.

Eaton, N. R. (2015). Hijab, religiosity, and psychological wellbeing of muslim women in the United States. Journal of Muslim Mental Health, 9(2), 25-40.

Husain, W., \& Aziz, N. (2014). The levels of body esteem among veiled and unveiled women. FWU Journal Os Social Sciences, 8(1), 46-49.

Husna, F. (2018). Niqab squad Jogja dan muslimah era kontemporer di Indonesia. Jurnal AlBayan, 24(1), 1-28. https://doi.org/10.1017/CBO9781107415324.004

Ilyas, K. (2019). Indadari ungkap curahan hati anggota Niqab Squad kenakan cadar di berbagai profesi. Indonesia: TV One.

Juliani, R. (2018). Stigmatisasi mahasiswa tentang maraknya mahasiswa bercadar di kampus. Jurnal Community, 4(1), 90-104.

Kudhori, M. (2019). Kontroversi hukum cadar dalam perspektif dialektika syariat dan adat. 
Ijtihad: Jurnal Wacana Hukum Islam Dan Kemanusiaan, 18(1), 33-56. https://doi.org/10.18326/ijtihad.v18i1.33-56

Leach, A., Ammar, N., England, D. N., Remigio, L. M., Kleinberg, B., \& Verschuere, B. J. (2016). Less is more? detecting lies in veiled witnesses. Law and Human Behavior, 40(4), 401-410.

Mahanani, P. A. R. (2017). Perempuan Salafi Memaknai Jilbab: Antara Alternatif dan Oposisional. Jurnal Sosial Politik, 2(1), 123. https://doi.org/10.22219/sospol.v2i1.4760

Mufid, M. (2012). Etika dan Filsafat Komunikasi (3rd ed.). Jakarta: Kencana.

Nasser, M. (1999). The new veiling phenomenon-is it an anorexic equivalent? A polemic. Journal of Community \& Applied Social Psychology, 412, 407-412.

Neill, B. O., Gidengil, E., Côté, C., \& Young, L. (2015). Freedom of religion, women's agency and banning the face veil: the role of feminist beliefs in shaping women's opinion. Ethic and Racial Studies, 38(11), 1886-1901. https://doi.org/10.1080/01419870.2014.887744

Notoatmodjo, S. (2009). Pengembangan Sumber Daya Manusia. Jakarta: PT Rineka Cipta.

Qolbi, K., \& Haidar, M. A. (2013). Makna penggunaan cadar mahasiswi Institut Keislaman Abdullah Faqih (INKAFA). Jurnal Paradigma, 1(3), 1-4.

Rahman, A. F., \& Syafiq, M. (2017). Motivasi, stigma dan coping stigma pada perempuan bercadar. Jurnal Psikologi Teori Dan Terapan, 7(2), 103-115.

Rasyid, L. A., \& Bukido, R. (2018). Problematika hukum cadar dalam Islam: sebuah tinjauan $\begin{array}{llll}\text { normatif-historis. } \quad J u r n a l & \text { Ilmiah } & \text { Al-Syir'ah, }\end{array}$ https://doi.org/10.1051/matecconf/201712107005

Ratri, L. (2011). Cadar, media, dan identitas perempuan muslim. Forum, 39(2), 29-37.

Sahfitri, H. D. A. (2017). Komunikasi intrapersonal pengguna cadar (Studi deskriptif kualitatif komunikasi intrapersonal pengguna cadar pada mahasiswi STAI As-Sunnah Tanjung Morawa). Jurnal Ilmu Komunikasi Flow, 3(10), 1-10. Retrieved from https://jurnal.usu.ac.id/index.php/flow/article/view/19241/8105

Sari, F. H., Lilik, S., \& Agustin, R. W. (2014). Studi fenomenologi mengenai penyesuaian diri pada wanita bercadar. Wacana Jurnal Psikologi, 6(11), 103-122.

Sircar, S. I. (2015). The veil and Muslim women: Prophetic tradition or Stage-managed Islam ? IOSR Journal of Humanities and Social Science (IOSR-JHSS), 20(10), 76-79. https://doi.org/10.9790/0837-201017679

Sudirman, M. (2018). Cadar bagi wanita muslimah dalam perspektif hukum Islam. AshShahabah: Jurnal Pendidikan Dan Studi Islam, 4(1), 55-63.

Sugiyono. (2014). Metode Penelitian Kombinasi (Mixed Methods) (5th ed.). Bandung: Alfabeta.

Tim Penyusun Kamus Pusat Bahasa. (2008). Kamus Bahasa Indonesia. https://doi.org/10.1192/bjp.111.479.1009-a 


\begin{tabular}{|l|l|l|l|l|}
\hline Submit & Review & Revisi & Diterima & Publis \\
\hline $04-10-2020$ & $05-10-2020$ sd 23-11-2020 & 23-11-2020 & 23-11-2020 & 27-1-2021 \\
\hline
\end{tabular}

Izzatur Rusuli

Institut Agama Islam Negeri (IAIN) Takengon Aceh

Email : izzaturrusuli10@gmail.com 